\title{
Making the Most of Fieldwork Education
}




\section{Making the Most of \\ Fieldwork Education}

A PRACTICAL APPROACH

\section{Auldeen Alsop}

South-bank University, London, UK

and

\section{Susan Ryan}

University of East London, UK

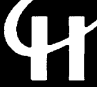

Springer-Science+Business Media, B.V. 
Distributed in the USA and Canada by Singular Publishing Group Inc., 428441 st Street, San Diego, California 92105

First edition 1996

(C) 1996 Auldeen Alsop and Susan Ryan Originally published by Chapman \& Hall in 1996. Typeset in Times 10/12pt by Saxon Graphics Ltd, Derby

ISBN 978-1-56593-439-9 ISBN 978-1-4899-3148-1 (eBook)

DOI 10.1007/978-1-4899-3148-1

Apart from any fair dealing for the purposes of research or private study, or criticism or review, as permitted under the UK Copyright Designs and Patents Act, 1988, this publication may not be reproduced, stored, or transmitted, in any form or by any means, without the prior permission in writing of the publishers, or in the case of reprographic reproduction only in accordance with the terms of the licences issued by the Copyright Licensing Agency in the UK, or in accordance with the terms of licences issued by the appropriate Reproduction Rights Organization outside the UK. Enquiries concerning reproduction outside the terms stated here should be sent to the publishers at the London address printed on this page.

The publisher makes no representation, express or implied, with regard to the accuracy of the information contained in this book and cannot accept any legal responsibility or liability for any errors or omissions that may be made.

A catalogue record for this book is available from the British Library

Library of Congress Catalog Card Number: 96-84232

Printed on permanent acid-free text paper, manufactured in accordance with ANSI/NISO Z39. 48-1992 and ANSI/NISO Z39.48-1984 (Permanence of Paper). 


\section{Contents}

Foreword vii

Introduction How to use this book ix

Part One PROFESSIONAL AND ORGANIZATIONAL CONTEXTS OF FIELDWORK 1

$1 \quad$ What is fieldwork education? 3

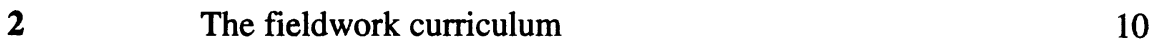

$3 \quad$ Fieldwork dynamics $\quad 14$

4 The context of fieldwork 20

$5 \quad$ Allocation of placements 32

6 Accreditation and qualities of the fieldwork educator 37

$\begin{array}{lll}\text { Part Two THE FIELDWORK EXPERIENCE } & 53\end{array}$

$7 \quad$ Setting the scene: expectations of you and others 55

$8 \quad$ Examining your needs 62

$9 \quad$ Taking responsibility $\quad 84$

10 The first few days 101

11 Participating in service delivery 116

12 Being supervised 130

13 Practising as s professional 144

14 Developing reasoning skills 155

15 Becoming a reflective learner $\quad 170$

16 Developing competence 186

17 Being assessed 197

18 Evaluating the fieldwork experience 206

19 Researching practice 210

20 Becoming qualified 225

$\begin{array}{lll}\text { Appendix A Useful addresses } & 231\end{array}$

Appendix B Relevant legislation in the UK 233

$\begin{array}{ll}\text { Index } & 235\end{array}$ 


\section{Foreword}

Fieldwork education, which combines work-based learning and assessment, has a pivotal place in professional education. It provides a precious opportunity to integrate the art, science and ethical practice of Occupational Therapy. The therapeutic milieu is also the most appropriate but difficult setting in which to judge 'competence to practise'. Yet fieldwork education has not received the attention, resources, research and status it deserves. This is why this book is so important.

The focus upon the students' experience reflects the central tenet of the book: the responsibility, challenge and pleasure of life-long learning. The book covers the whole spectrum of fieldwork in a way which will be of interest to academic and fieldwork educators too. This is achieved through a striking balance between reassuring, practical advice and scholarliness. The reader is encouraged to enter into current debates, engage in inter-disciplinary and international comparisons and appreciate the tensions between professional issues and organizational contexts. The insights into the logistical, political and educational factors which contribute to the theory-practice gap are noteworthy.

In my view, the authors have produced an excellent introduction to fieldwork education, and especially to the complexities of clinical reasoning which is a vital component of initial and continuing competence for many professions. I hope the book will enhance the effectiveness of fieldwork education and thus the quality of health and social care.

Irene Ilott, PhD, M.Ed Dip.COT SROT

First Alternate to the UK Delegate to the World Federation of Occupational Therapists 


\section{Introduction: How to use this book}

Our primary aim was to write a book about fieldwork for you, the student, to help you make the most of this essential component of your professional education. We also hope that fieldwork educators, academics and other professionals involved in fieldwork education will use the text to enhance their understanding of the experience of fieldwork. Our purpose is to provide you with information that will enable you to capitalize on opportunities that you have for learning during your fieldwork experience, and perhaps even afterwards, when you are qualified.

In these times of rapid change it is necessary for professionals to think, plan and act autonomously and take charge of their own affairs, but to do this they need a solid foundation of knowledge. We hope that this book will provide a means for you to develop that knowledge base and to learn how to use it effectively in practice. The contents do not, however, merely relate to enhancing your knowledge base. They focus on processes of learning to enable you to maximize opportunities and use learning experiences effectively wherever you are. We avoid being prescriptive so you will not find details of specific ways of working. Instead we try to help you to understand how the complex system of fieldwork education actually works and the role that you have to play within the system. We show you how to participate actively in the experience and so benefit from it.

First we explain how we have organized the book.

We have written the book so that you can read it straight through or dip into chapters that are relevant to your needs at a specific time. Each chapter contains what we believe to be essential information on the subject addressed. You will therefore find some overlap of material across certain chapters. At the beginning of each chapter we list the major points that will be covered, and at the end we summarize the main details. We have also organized the book so that it covers the complete spectrum of the fieldwork experience. This includes the preparatory time at university before the placement, the actual time while you are in the fieldwork setting and the period of adjustment after your placement, which might entail settling back into university or going forward as a qualified practitioner.

Sometimes it is hard to make a connection between all the components of fieldwork when it is new to you. Studies have illustrated how it helps to use visualization to gain an understanding of the elements of a situation and the connections between them. This is why we have used figures throughout the text to reinforce key 
points. You could draw figures for yourself, in your own way, as you try to understand the relationships between the different components. The introductory figure below illustrates our vision of the main elements of the book. We see it like a wheel with you and the fieldwork experience as the hub surrounded by all sorts of knowledge, organizational contexts and learning opportunities which are relevant to you in the fieldwork situation.

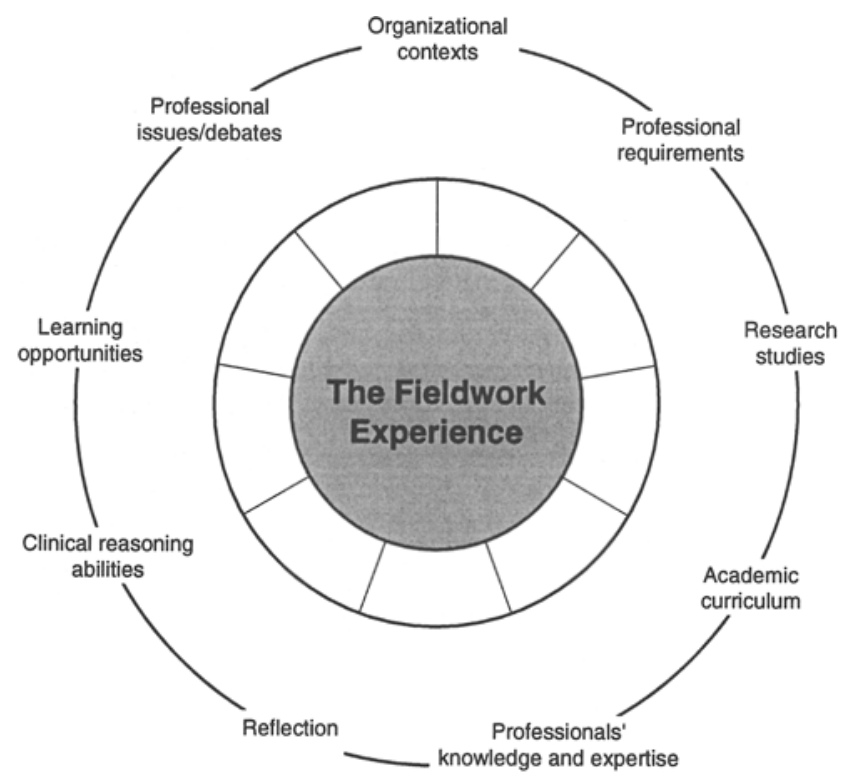

Introductory figure The wheel of fieldwork experience

The text is divided into two parts. The first part outlines the professional and organizational contexts of fieldwork education and the second presents the fieldwork experience in chronological order. We draw on material from a wide range of sources: personal experience, professional resources, published work, findings from research studies, literature about adult learning theories and professional development, clinical reasoning and reflection principles. Your needs and responsibilities and the process of professional development are examined in depth. There are ideas and exercises to help you enhance your learning and case stories help illustrate the points we make. Each part is now explained in a little more detail.

\section{PART ONE}

In Part One we set the scene and give you background information about fieldwork education. You will find this a useful reference at different times during your professional education. Fieldwork is examined from many perspectives. We explain how it is organized, how it fits into the overall curriculum and we consider the aims 
and purpose of this part of your educational programme. We then explain some of the current debates for the profession about fieldwork education. We try to present different perspectives on the issues so that you can form an opinion of your own. The chapters in this part show that fieldwork is actually quite complex, but it is an extremely important part of your professional education.

\section{PART TWO}

The chapters in this part follow the chronological order of the actual fieldwork experience from beginning to end. Woven into the text at appropriate times are chapters on ways of enhancing your learning, of improving your clinical reasoning skills, and of using reflection to augment the whole event. We highlight the things that you can actively do for yourself to maximize your learning opportunities and to ensure that you feel in control of the experience. You will also find that you can go back to the book at different stages of your education and use it as your needs change. You will find that you will need different kinds of information each time you go on a placement. Fieldwork education will make many demands on you. This book should provide you with the knowledge that will enable you, not only to gain the most from your experience, but also to give you the confidence to enjoy it.

In the book we refer to Occupational Therapy since we have written the book primarily for this profession. Many of the ideas are, however, transferable to other professions and could be used to enable students of other professional groups to gain the most from their own experience of learning through practice. 